Abstracta Iranica Abstracta Iranica

Revue bibliographique pour le domaine irano-aryen

Volume 26 | 2005

Comptes rendus des publications de 2003

\title{
La memoria romana dei santi martiri persiani Mario, Marta, Audiface e Abaco. Roma, Aracne, 2003, 32 p.
}

\section{Charles-Henri de Fouchécour}

\author{
(2) OpenEdition \\ Journals \\ Édition électronique \\ URL : http://journals.openedition.org/abstractairanica/3484 \\ ISSN : 1961-960X \\ Éditeur : \\ CNRS (UMR 7528 Mondes iraniens et indiens), Éditions de l'IFRI \\ Édition imprimée \\ Date de publication : 15 mai 2005 \\ ISSN : 0240-8910 \\ Référence électronique \\ Charles-Henri de Fouchécour, «La memoria romana dei santi martiri persiani Mario, Marta, Audiface e \\ Abaco. Roma, Aracne, 2003, 32 p. », Abstracta Iranica [En ligne], Volume 26 | 2005, document 166, mis \\ en ligne le 08 décembre 2005, consulté le 25 septembre 2020. URL : http://journals.openedition.org/ \\ abstractairanica/3484
}

Ce document a été généré automatiquement le 25 septembre 2020.

Tous droits réservés 


\title{
La memoria romana dei santi martiri persiani Mario, Marta, Audiface e Abaco. Roma, Aracne, 2003, 32 p.
}

\author{
Charles-Henri de Fouchécour
}

A l'occasion de l'anniversaire de l'érection de la paroisse romaine dédiée à saint Mario et à sa famille, martyrs, le savant auteur a pu confronter les données hagiographiques locales et les données historiques, et montrer que les quatre martyrs composaient une famille noble de Perse, venue vénérer les reliques des saints apôtres à Rome, où elle connut le martyre. On connaît une Passio latine (les Acta sanctorum Iannarii Tomus II), hagiographie des $5^{\mathrm{e}}$ et $6^{\mathrm{e}}$ siècles, mentionnant le martyre des saints Marius, Marthe et leurs fils Audifax et Abbacuc, sous l'empereur Claude II le Goth (268-270). En fait, ce n'est pas lui, mais Dioclétien, en 303, qui persécuta les chrétiens auxquels renvoie le récit. Ce récit de martyre est un stéréotype sur le schéma: pèlerinage, conversion et martyre. L'A. peut établir que Marius et les siens furent victimes de cette vaste persécution. Un rapprochement entre le nom du père de Marthe, Cusinitis, avec celui d'un satrape d'ascendance parthe en Arménie chrétienne, Xûžên, met sur la voie d'une identification des autres noms (Avdifax et Abdvaxš, 'doué d'esprit admirable'; Abbacuc et Habbaquq, le prophète qui secourut Daniel dans la fosse, Daniel très vénéré en Perse). Trente-trois pages d'une érudition impressionnante, où il est question de l'histoire des reliques des saints, du sanctuaire qui les abrita et des fêtes jubilaires qui perpétuent la mémoire de ces authentiques martyrs. 
INDEX

Thèmes : 3.2.3. Séleucides, Parthes et Sassanides

\section{AUTEURS}

CHARLES-HENRI DE FOUCHÉCOUR

Fondateur de la revue Abstracta Iranica - Paris 